\title{
PENGARUH TINGKAT PEMUPUKAN NITROGEN DAN NAUNGAN TERHADAP KERAGAAN DAN KANDUNGAN PROTEIN KASAR RUMPUT Brachiaria humidicola
}

\author{
Juneidid S. Togelang*, D.A. Kaligis, F. Dompas, N. Bawoleh
}

Fakultas Peternakan Universitas Sam Ratulangi Manado, 95115

\begin{abstract}
ABSTRAK
Penelitian ini bertujuan untuk mengkaji pengaruh pemupukan nitrogen dan naungan terhadap keragaan dan kandungan protein kasar rumput $B$. humidicola. Perlakuan yang diuji terdiri dari empat level pupuk nitrogen dalam bentuk pupuk urea : $\mathrm{P}_{1}=0$ $\mathrm{kg} / \mathrm{Ha}, \mathrm{P}_{2}=50 \mathrm{~kg} / \mathrm{Ha}, \mathrm{P}_{3}=100 \mathrm{~kg} / \mathrm{Ha}, \mathrm{P}_{4}=$ $150 \mathrm{~kg} / \mathrm{Ha}$, dan tiga level naungan $\mathrm{N}_{1}=0 \%, \mathrm{~N}_{2}$ $=40 \%$ dan $\mathrm{N}_{3}=70 \%$. Perlakuan diatur secara faktorial pada rancangan dasar acak kelompok (RAK). Data dianalisis dengan menggunakan Minitab Versi II, dan uji lanjut dengan Turkey Simultaneous Test. Hasil penelitian menunjukan jumlah anakan rumput $B$. humidicola tertinggi diperoleh pada interaksi perlakuan $\mathrm{P}_{3} \mathrm{~N}_{1}, \mathrm{P}_{4} \mathrm{~N}_{1}, \mathrm{P}_{2} \mathrm{~N}_{2}$ dan $\mathrm{P}_{3} \mathrm{~N}_{2}$, yang berbeda nyata $(\mathrm{P}<0,05)$ lebih tinggi dibandingkan dengan interaksi perlakuan lainnya. Selanjutnya hasil analisis keragaman menunjukan interaksi perlakuan berpengaruh nyata $(\mathrm{P}<0,05)$ dimana interaksi perlakuan $\mathrm{N}_{1} \mathrm{P}_{4}$ mengandung protein kasar $9,74 \%$ yang nyata $(\mathrm{P}<0,05)$ lebih tinggi dibandingkan dengan interaksi perlakuan lainnya. Dilain pihak interaksi perlakuan tidak berpengaruh nyata $(P>0,05)$ terhadap rasio daun : batang. Dari hasil penelitian ini dapat disimpulkan bahwa hijauan pakan $B$. humidicola responsif terhadap pemupukan urea sampai dengan 100 $\mathrm{kg} / \mathrm{Ha}$ untuk menghasilkan keragaan dan kandungan protein kasar yang optimal pada kondisi lingkungan ternaung sampai $40 \%$.
\end{abstract}

Kata Kunci : Nitrogen, Kandungan Protein Kasar Rumput $B$. humidicola.

*Korespondensi (corresponding author):

Email: swaneketogelang@yahoo.com

\section{ABSTRACT}

THE EFFECTS OF NITROGEN FERTILIZER AND SHADING LEVELS ON PERFORMANCE AND CRUDE PROTEIN CONTENT OF Brachiaria humidicola. The aim of this experiment was to study the effects of different levels of shading and nitrogen on the performance and nitrogen content of B. Humidicola. The treatment were consisted of four levels of nitrogen in from of urea fertilizer: $\mathrm{P}_{1}=0 \mathrm{~kg} / \mathrm{Ha}, \mathrm{P}_{2}=50 \mathrm{~kg} / \mathrm{Ha}, \mathrm{P}_{3}$ $=100 \mathrm{~kg} / \mathrm{Ha}, \mathrm{P}_{4}=150 \mathrm{~kg} / \mathrm{Ha}$, and three levels of shading: $\mathrm{N}_{1}=0 \%, \mathrm{~N}_{2}=40 \%$ dan $\mathrm{N}_{3}=70 \%$. Treatmens was arranged in infactorial based on ramdomized block design (RBD). Date was analysis by using Minitab Version 11, and followed with Turkey Simultaneous Test, to determined the different among treatments, from analysis of variance. The result showed the higher number of tiller was found at the interaction of $\mathrm{P}_{3} \mathrm{~N}_{1}, \mathrm{P}_{4} \mathrm{n}_{1}, \mathrm{P}_{2} \mathrm{~N}_{2}$ and $\mathrm{P}_{3} \mathrm{~N}_{2}$, with significantly different compared to the other interactions. Furthermore, analysis of varians showed the interaction of the treatments were effected significantly on the content of crude protein $(\mathrm{P}<0,05)$ where the interaction of $\mathrm{N}_{1} \mathrm{P}_{4}$ has the crude protein content $9,74 \%$ significantly higher $(\mathrm{P}<0,05)$ compared to other interactions. On the other hand the interaction of the treatments was not effected significantly $(\mathrm{P}<0,05)$ on the leaf: steam ratio. Based on the result of this experiment it can be concluded that $B$. humidicola responsive to nitrogen farilizer up to $100 \mathrm{~kg}$ urea/Ha to provide optimal performance and crude protein content under shade of $40 \%$.

Keywords: Nitrogen, Shading Performance, Crude Protein, humidicola. 


\section{PENDAHULUAN}

Salah satu faktor yang membatasi peningkatan produksi ternak ruminansia adalah kurangnya ketersedian hijauan pakan bermutu dan berkelanjutan. Peternak mengandalkan rumput alam yang baik produksi dan kualitas rendah serta turun drastis pada musim kemarau.

Rumput B. humidicola adalah salah satu rumput gembala yang memiliki produksi lebih baik, memiliki nilai nutrisi yang tinggi, lebih tahan pada musim kemarau dan cocok untuk daerah tropis (Anis dan Kaligis 2012). Rumput ini berasal dari daerah Afrika (Uganda, kenya, tanzania) dan mulai di introduksi ke Indonesia tahun 1958 (Siregar dan Djajanegara, 1971). Seiring dengan penelitian breeding dan penemuan ciltivarcultivar baru rumput Brachiaria diantaranya Brachiaria brizantha Stapf, Brachiaria decumbens, Brachiaria humidicola, Brachiaria ruziziensis, Brachiaria dictyoneura, Brachiaria distachya. Khusus rumput Brachiaria humidicola (Rendle) Schweich cv. Tully diintroduksi ke Sulawesi Utara dari Australia tahun 1989 (Kaligis and Sumolang, 1991).

Nitrogen merupakan unsur esensial bagi pertumbuhan tanaman sebab itu tanpa nitrogen pertumbuhan tanaman akan terhambat. Untuk memenuhi kebutuhan tanaman akan unsur ini, diberi sumber nitrogen dalam bentuk pupuk urea (Salisbury and Ross, 1995 Whitehead, 2000). Naungan berpengaruh terhadap suhu pada tingkat kanopi dan suhu pemupukan tanah, dan keterbatasan cahaya karena naungan mempengaruhi proses fotosintesis (Bona and Monteiro 2010). Namun demikian turunnya suhu udara lingkungan mikro karena naungan turut mempengaruhi aktifitas mikroorganisme tanah yang berperan dalam perombakan bahan organik dengan tanah. Penelitian ini dilaksanakan untuk mengetahui pengaruh pempukan nitrogen dan tingkat naungan terhadap kandungan protein kasar dan perkembangan morfologi rumput $B$. Humidicola.

\section{MATERI DAN METODE PENELITIAN}

Penelitian ini telah dilaksanakan di Desa Buha pada Balai Pengkajian dan Penerapan Teknologi Pertanian (BPPTP), selama 2 bulan. Bahan yang digunakan dalam penelitian ini adalah anakan rumput B. humidicola yang diambil dari kebun percobaan Fakultas Peternakan UNSRAT, pupuk urea, pupuk TSP dan KCL. Alat yang digunakan adalah paranet dengan tingkat naungan $40 \%$ dan $70 \%$, termometer suhu maximum dan minimum, 
timbangan, sprayer, serta peralatan untuk keperluan panen dan penaungan sampel.

Perlakuan yang diuji dalam penelitian ini adalah tingkat penggunaan pupuk nitrogen (Faktor A) dengan dosis pupuk urea $\mathrm{P}_{1}=0 \mathrm{Kg} / \mathrm{Ha}, \mathrm{P}_{2}=50 \mathrm{Kg} / \mathrm{Ha}$, $\mathrm{P}_{3}=100 \mathrm{Kg} / \mathrm{Ha}$, dan $\mathrm{P}_{4}=150 \mathrm{Kg} / \mathrm{Ha}$, sedangkan Faktor B adalah tingkat naungan $\mathrm{N}_{1}=0 \%, \mathrm{~N}_{2}=40 \%$, dan $\mathrm{N}_{3}=$ $70 \%$. Perlakuan di tempatkan secara Faktorial pada rancangan percobaan acak Kelompok (RAK) dengan dua ulangan. Pengelompokan didasarkan pada perbedaan jenis vegetasi yang ada pada lahan tersebut sebelum diolah menjadi petak percobaan. Lahan yang digunakan dibersihkan dari gulma dan untuk dapatkan media tumbuh yang siap tanam, tanah dibongkar dan dihaluskan dengan menggunakan cangkul sehingga didapatkan partikel tanah yang lebih kecil kemudian diratakan. Lahan dibiarkan selama tiga minggu sampai semua gulma tumbuh kembali dan dikontrol dengan herbisida Roundup. Selanjutnya dibuat petakan 3 x 3 meter. Anakan $B$. humidicola ditanaman di setiap petak dengan jarak tanam $30 \mathrm{~cm}$ x $30 \mathrm{~cm}$, dibiarkan selama 30 hari kemudian dilakukan trimming untuk dapatkan pertumbuhan yang seragam. Pupuk dasar TSP dan KCL diberikan bersamaan pada saat pengolahan lahan dengan dosis masing - masing $75 \mathrm{~kg} / \mathrm{Ha}$. Sedangkan pupuk urea sebagai perlakuan diberikan pada tiap petak sesuai dosis perlakuan yang diuji pada umur pertumbuhan kembali satu minggu setelah trimming. Paranet dipasang menutupi setiap petak sesuai perlakuan dengan tingkat naungan $40 \%$ dan $70 \%$ setelah trimming. Untuk menyangga paranet digunakan kayu dan bambu dengan ketinggian naungan satu meter dari permukaan tanah. Panen dilakukan pada umur 30 hari setelah trimming. Panen dilakukan dengan cara memotong rumput $B$. humidicola setinggi $10 \mathrm{~cm}$ diatas permukaan tanah. Pengambilan sampel dilakukan dengan menggunakan bingkai bujur sangkar berukuran 100 x $50 \mathrm{~cm}$ sebanyak 2 cuplikan per petak kemudian campur merata dan diambil sampel sebanyak $2 \mathrm{~kg}$ segar. Setelah sampel dapatkan berat kering tetap, digiling sampai halus, kemudian dimasukan kembali kedalam oven pada suhu $105{ }^{0} \mathrm{C}$ selama 24 jam untuk mendapatkan kandungan bahan kering. Selanjutnya kandungan protein kasar dilakukan analisis nitrogen dengan menggunakan metode Mikro Kjedahl di Laboratorium Lahan Tanah Fakultas Peternakan UNSRAT.

\section{HASIL DAN PEMBAHASAN}

Jumlah Anakan Rumput B. humidicola 
Tabel 1. Pengaruh Interaksi Pupuk Nitrogen dan Naungan Terhadap Jumlah Anakan Rumput $B$. humidicola.

\begin{tabular}{cccc}
\hline & \multicolumn{3}{c}{ Naungan } \\
\cline { 2 - 4 } Pupuk & $0 \%$ & $40 \%$ & $70 \%$ \\
\hline 0 & 131.00 & 135.25 & 161.87 \\
50 & 151.00 & 174.12 & 150.37 \\
100 & 196.37 & 168.87 & 159.12 \\
150 & 175.75 & 143.87 & 135.00 \\
\hline
\end{tabular}

Ket. Superskrip berbeda pada lajur yang sama menunjukkan berbeda nyata $(\mathrm{P}<0.05)$

Analisis keragaman menunjukan interaksi perlakuan berpengaruh nyata ( $\mathrm{P}$ $<0.05$ ) terhadap jumlah anakan rumput percobaan. Hasil uji lanjut dengan Tukey Simultaneous Test menunjukan jumlah anakan tertinggi diperoleh pada interaksi perlakuan $\mathrm{P}_{3} \mathrm{~N}_{1}$ dan diikuti oleh masing masing perlakuan $\mathrm{P}_{4} \mathrm{~N}_{1}, \mathrm{P}_{2} \mathrm{~N}_{2}$ dan $\mathrm{P}_{3} \mathrm{~N}_{2}$, berbeda nyata lebih tinggi dibandingkan interaksi perlakuan lainnya. Pada Tabel 1 terlihat jumlah anakan dipengaruhi oleh tiga kategori interaksi sebagai berikut:

Pertama, level pupuk nitrogen pada kondisi lingkungan tanpa naungan $\left(\mathrm{N}_{1}\right)$ peningkatan jumlah anakan sampai level $100 \mathrm{~kg} / \mathrm{Ha} \quad\left(\mathrm{P}_{3}\right)$. Kedua pada kondisi lingkungan dengan naungan $40 \%$ jumlah anakan masi dipengaruhi oleh pemberian pupuk nitrogen sampai level $100 \mathrm{~kg}$ urea/Ha, kemudian menurun walaupun tidak nyata pada level pemupukan sampai $150 \mathrm{~kg}$ urea/Ha. Ketiga kendatipun diberikan pupuk nitrogen, pada kondisi lingkungan ternaung $70 \%$ pemupukan nitrogen tidak dapat menaikkan jumlah anakan, bahkan terjadi penurunan dibanding pada perlakuan tanpa naungan $\left(\mathrm{N}_{1}\right)$ dan naungan $40 \%\left(\mathrm{~N}_{2}\right)$. Hasil ini menunjukkan bahwa untuk dapatkan jumlah anakan yang optimal pada kondisi lingkungan tanpa naungan dan dengan naungan $40 \%$ level pemupukan nitrogen yang efisien adalah $100 \mathrm{~kg}$ urea/Ha. Nitrogen sampai dengan $100 \mathrm{~kg} / \mathrm{Ha}$ dapat menghasilkan jumlah anakan terbanyak. Demikian juga pada kondisi naungan $40 \%$ level pupuk interaksi hanya efektif sampai dengan $100 \mathrm{~kg}$ urea/Ha untuk dapatkan jumlah anakan tertinggi.

\section{Protein Kasar}

Hasil analisis varians menunjukkan interaksi perlakuan berpengaruh nyata $(\mathrm{P}<$ 0.05) terhadap kandungan protein kasar. Dengan uji lanjut diperoleh interaksi $\mathrm{N}_{1} \mathrm{P}_{4}$ menghasilkan kandungan protein kasar sebanyak 9,74\% nyata lebih tinggi $(\mathrm{P}<$ 0.05) dibandingkan dengan interaksi 
Tabel 2. Pengaruh Interaksi Level Pupuk Nitrogen dan Level Naungan Terhadap Kandungan Protein Kasar Rumput B. humidicola.

\begin{tabular}{cccc}
\hline & \multicolumn{3}{c}{ Naungan } \\
\cline { 2 - 4 } Pupuk & $0 \%$ & $40 \%$ & $70 \%$ \\
\hline 0 & 7.416 & 8.407 & 8.353 \\
50 & 7.730 & 8.220 & 8.747 \\
100 & 8.897 & 8.820 & 8.617 \\
150 & 9.740 & 8.143 & 7.907 \\
\hline
\end{tabular}

Ket. Superskrip berbeda pada lajur yang sama menunjukkan berbeda nyata $(\mathrm{P}<0,05)$

perlakuan lainnya. Hal ini mungkin berkaitan juga dengan kemampuan rumput B. humidicola meningkatkan efisiensi penggunaan $\mathrm{N}$ dalam tanah (Subarao et al., 2009). Tingginya kandungan protein kasar pada level pemupukan nitrogen $150 \mathrm{~kg}$ urea/Ha terjadi karena berinteraksi positif dengan kondisi lingkungan tanpa naungan $\left(\mathrm{N}_{1}\right)$, yang menyebabkan proses fotosintesis berlangsung optimal (Feng et al., 2008), dan bahwa sintesis protein pada hijauan pakan erat kaitannya dengan proses fotosintesis dan tergantung pada energi yang berasal dari cahaya matahari (Bona and Montteiro, 2010; Schmit et al., 2013). Sedangkan pada kondisi lingkungan ternaung $40 \%$ dan $70 \%$ kendatipun diberikan level pupuk $\mathrm{N}$ sampai dengan $150 \mathrm{~kg}$ urea/Ha hanya dapat menaikkan kandungan protein kasar setara dengan pemupukan $100 \mathrm{~kg}$ urea/Ha pada kondisi tanpa naungan $\left(\mathrm{N}_{1}\right)$, bahkan turun setara dengan pada level pemupukan $50 \mathrm{~kg}$
urea/Ha walaupun diberi pupuk $150 \mathrm{~kg}$ urea/Ha.

\section{KESIMPULAN}

Dari hasil penelitian ini dapat disimpulkan bahwa hijauan pakan Brachiaria humidicola responsif terhadap pemupukan urea sampai dengan $100 \mathrm{~kg} / \mathrm{Ha}$ untuk menghasilkan keragaan dan kandungan protein kasar yang optimal pada kondisi lingkungan ternaung sampai $40 \%$.

\section{DAFTAR PUSTAKA}

Anis, S.D dan D. A Kaligis . 2012. Karakteristik dan pola tumbuh Brachiaria cv Tully di areal Tegakan kelapa. Prosiding Seminar Nasional Pembangunan Peternakan berkelanjutan. UNPAD. Jatinangor.

Bona, D and F.A. Montteiro. 2010. The development and production of leaf and tillers by Marundu Palisadegrass ferthized with 
nitrogen and sulphur. Tropical Grassiand 44: 192-201.

Feng et al. 2008. Specific leaf area related to the differences in leaf construction nitrogen allocation and use efficiency between invasive and invasive alien congeners. Planta $228: 390$.

Kaligis, D.A and C. Sumolang.1991. Forage species Forcoconut Plantantiom in North Sulawesi In forage for Plantion Crops. Ed.: H.M. Shelton and W.W. Stur. ACIAR Proc. No 32.

Salisbury, F.B and C.W. Ross. 1995. Fisiologi Tumbuhan. Jilid I. D.R Lukman dan Sumaryono (Penerjemah). Terjemahan dari:
Plant Physiology. ITB press Bandung.

Schmit, A., J. Pausch and Y. Kuzyakov. 2013. Effect of clipping and on $\mathrm{C}$ allocation and fluxes in soil under Ryegrass and Alfalfa astemared by $\mathrm{C}^{14}$ labelling.Appl. Soil Ecology 64 : 228-236.

Subbarao et al. 2009. Evidence for biological nitrification inhibition in Brachiaria humidicola pasture. Agricultural Sci. 106 (41):1730217307.

Whitehead, D.C. 2000. Nutrient Element in Grassland: Soil-Plant-Animal Relationships. $\mathrm{CAB}$ International. United Kingdom 